\title{
Making the green economy: politics, desire, and economic possibility
}

\author{
Boone W. Shear ${ }^{1}$ \\ University of Massachusetts Amherst, USA
}

\begin{abstract}
The green economy is put forward as an apposite remedy to both economic crisis and ecological devastation. Policy makers, academics, corporate interests and activists are advancing their goals as part of and through the green economy, a discursive terrain full of circulating and competing ideas about, dispositions towards, and desires for the economy. In Massachusetts, broad-based coalitions involving labor, environmentalists and community groups have emerged to capture funding, influence policy and launch their own economic initiatives. This paper explores and compares the activities of two green economy coalitions. I investigate how social actors, including myself, have been negotiating, responding to, and producing the meaning of the green economy, and the meaning of "the economy" writ-large, through our political efforts. I aim to move beyond a project that only critiques capitalism or maps out capitalist hegemony. Instead, taking inspiration and drawing from J.K. Gibson-Graham I look to theorize and amplify non-capitalist initiatives and enterprises. I am particularly interested in thinking about the ways in which the expression of different desires for economy can lead to openings, or closures, for the construction of non-capitalist relationships, initiatives, and enterprises
\end{abstract}

Key words: green economy, economic subjectivity, Gibson-Graham, non-capitalism, fantasy

\section{Résumé}

L'économie verte est mise en avant comme un remède pertinent à la fois la crise économique et la dévastation écologique. Les décideurs politiques, les universitaires, les intérêts des entreprises et des militants avancent leurs objectifs dans le cadre de, et par l'économie verte, un terrain discursive pleine de circulation et d'idées concurrentes sur, dispositions à l'égard, et les désirs de l'économie. A Massachusetts, de coalitions impliquant les travailleurs, les écologistes et les groupes communautaires ont vu le jour pour assurer le financement, la politique de l'influence et de lancer leurs propres initiatives économiques. Cet article explore et compare les activités des deux coalitions de l'économie verte. J'étudie comment les acteurs sociaux, y compris moi-même, ont négocié, en réponse à, et produisent le sens de l'économie verte. Le sens de «l'économie» est produite par des efforts politiques. Je cherche à aller plus loin que la critique du capitalisme ou la cartographie de l'hégémonie capitaliste. Au lieu de cela, en s'inspirant de J.K. Gibson-Graham, je théoriser et d'amplifier les initiatives et des entreprises non-capitalistes. Je suis particulièrement intéressé par la réflexion sur la façon dont les initiatives et les entreprises peut conduire à des ouvertures ou fermetures, et l'expression des désirs économique pour la construction des relations non-capitalistes.

Mots clés: L'économie verte, la subjectivité économique, Gibson-Graham, non-capitalisme, l'imaginaire

\section{Resumen}

La economía verde es presentada como un remedio a la crisis económica y a la devastación ecológica. Formuladores de política, académicos, intereses corporativos y activistas están avanzando en sus objetivos como parte de y a través de la economía verde, un terreno discursivo lleno de ideas circulando y compitiendo acerca de, disposiciones hacia, y deseos por la economía. En Massachusetts, coaliciones amplias que involucran grupos de trabajo, de ambientalistas y la comunidad han emergido para capturar financiamiento, influenciar la política e impulsar sus propias iniciativas económicas. Este artículo explora y compara las actividades de dos coaliciones de economía verde. Investigo cómo actores sociales, incluyéndome a mí mismo, han estado negociando, respondiendo a, y produciendo el significado de economía verde, y el

\footnotetext{
${ }^{1}$ Boone Shear, PhD student, Department of Anthropology, University of Massachusetts Amherst, USA. Email: bwshear "at" yahoo.com. This research was supported by a Wenner-Gren Foundation Dissertation Fieldwork Grant. Thanks to Stephen Healy, Brian Burke, Casey Walsh, Christopher Sweetapple, Elizabeth Krause, and Yahya Madra for helpful feedback. Thanks to my daughter Rose for being fantastic. This is the fifth paper in Burke, B.J. and B.W. Shear (eds.) 2014. "Non-capitalist political ecologies", special section of the Journal of Political Ecology 21: 127-221.
} 
significado de "la economía", a través de nuestros esfuerzos políticos. Mi objetivo es ir más allá de un proyecto que solamente critica el capitalismo o traza la hegemonía capitalista. Por el contrario, inspirado y enmarcado por J.K. Gibson-Graham busco teorizar y ampliar iniciativas y empresas no-capitalistas. Estoy particularmente interesado en pensar acerca de los caminos en los cuales la expresión de diferentes deseos para la economía puede provocar aperturas, o cierres, para la construcción de relaciones, iniciativas, y empresas no-capitalistas.

Palabras clave: Economía verde, subjetividad económica, Gibson-Graham, no-capitalismo, fantasía

\section{Introduction}

On a late February evening in 2009, I went to a meeting of the Western Massachusetts Green Economy Working Group (Greenwork) at the Central Labor Council in Springfield, MA, pulling up in front of the one-story, concrete building located on a commercial strip a few miles east of downtown. I arrived early in order to meet David, one of the group's founders and a long time activist and community organizer whose current project was the creation of a non-profit intended to develop community-owned, renewable energy. We had exchanged emails in advance of the meeting, and he had invited me to come and talk with him beforehand to discuss what my "interest in the group was about." I walked in the front door and down the hall, past the offices of Western Mass Jobs with Justice, Western MassCosh and a few labor unions. I found him in a small kitchen towards the back of the building getting refreshments ready for the meeting. As I helped him set out some left over snacks and reheat a container of Dunkin Donuts coffee in the building's largest meeting room, I explained that I was interested in the possible convergence of green economy discourse and politics with alternative economic practices and institutions. At this his eyes lit up and we talked fervently about the possibilities for new political alliances and economic opportunity in the green economy as meeting-goers began to fill the room: community organizers, union reps., a couple academics (including myself), a small business owner, a workforce development official, a non-profit director and more. The evening's guest speaker was State Senator Benjamin Downing who had helped usher in a series of much discussed "green" legislation the year before that promised great investment in renewable energy and energy efficiency projects. There was soon to be an incredible amount of green economy money and efforts in the state, Downing explained. "Everything will be green soon", he said. "It will permeate everything".

The rest of the meeting was filled with excited talk and questions about how to access grants and funding, how to make sure that community groups, organized labor, people of color, and poor people would not be excluded from these new opportunities, and how to develop Greenwork into a group that could help create a green economy that would serve the interests of local communities. As the meeting was breaking up, I hung around a bit in order to speak with David as well as with the other primary founder of the group, a local community-labor organizer who I had met through my earlier work as a staff member of the graduate student union a few years before. We agreed that it was a fantastic meeting. It was clear that the green economy was bringing together people and organizations who might not have otherwise worked together around a project of influencing the emergence of, and in fact helping to create, a new economy. We talked about the opportunities for alternative economic projects—community ownership of energy, green worker cooperatives and so on. Stating what we were all feeling, David said, "we have an opportunity here to really change things."

The above account reflects the great amount of political energy mobilizing around and through green economy discourse, politics and organizing in 2008 and 2009. In Massachusetts, as in other parts of the United States, coalitions and organizations were seemingly springing up everywhere with names like Greenwork, The Massachusetts Green Jobs Coalition, The Green Justice Coalition, the Worcester Green Jobs Coalition, The Green Jobs Consortium and so on. New political alliances were forming around new campaigns and initiatives to capture funding, influence policy, and create new enterprises. From the perspective of many green economy coalition members and activists, at that time the green economy was something in the midst of being created, its composition not yet complete and its boundaries unknown. Many activists and organizers remember those early days as a time when the green economy offered political 
openings, possibility and inspiration ${ }^{2}$ : "I was hopeful. It seemed like anything was possible"; " [There was] this incredible sense of possibility and it was great. How many hour long potlucks [discussing ideas]?!; "Man, that was it, that's where it was happening"; "Everyone was excited about it. Things were wide open." ${ }^{3}$

This sense of promise and possibility was perhaps most powerfully expressed by Van Jones, one of the leading figures of the green economy movement, whose framing of the political scene was highly influential for many progressive activists and organizations. In his 2008 bestseller, The Green Collar Economy, Jones proposed the formation of a multi-class, populist alliance-what Gramsci might describe as a new "historical bloc" (Gill 2008: 60-61; Hall 1987: 21)—in which progressive interests could articulate around the idea that the construction of the green economy should benefit all social groups, as well as the environment. Like Obama, who appointed Jones to his cabinet (before he unceremoniously resigned while under public pressure fomented in part by the conservative pundit Glen Beck), the green economy was cresting on a wave of hope for a better world.

I have been exploring the activities of green economy groups in Massachusetts since 2009 while participating as an active member of the aforementioned Greenwork. ${ }^{4}$ Shortly thereafter, I began more formalized participant observation while working alongside two additional green economy groups. These broad-based coalitions involve community organizing groups, activists, organized labor, academics, students, environmentalists and small business owners. I have taken an active, participatory role in each group; I have helped to plan events, organized public meetings, participated in actions, given public testimony, written oped pieces, helped to write organization literature, and engaged in internal conversations and external debates. I have taken regular field notes (where appropriate and when permitted) and I have conducted over two dozen interviews with members from the two coalitions.

In this paper I explore how social actors, including myself, have been negotiating, responding to, and producing the meaning of the green economy, and the meaning of "the economy" writ-large, through our political efforts. I look to move beyond a project that only critiques capitalism or maps out capitalist hegemony. Instead, taking inspiration and drawing from J.K. Gibson-Graham (1996; 2006), I look to theorize and amplify non-capitalism, a concept which I discuss in more detail in the following section but I will imperfectly define here as economic initiatives and enterprises that can encourage collective and ethical decision making rather than individualism, exploitation and market logics. ${ }^{5}$ I am particularly interested in thinking about the ways in which the expression of different desires for economy can lead to openings, or closures, for the construction of non-capitalist relationships, initiatives, and enterprises.

In the first section I sketch out the contours of the mainstream, green-economy project emanating from the state that social actors are immersed in and negotiate in Massachusetts. I recapitulate a politicaleconomic account of the green economy and link it to neoliberal governance. I provide this outline of a "strong theory" of capitalism (Gibson-Graham 2006: 5, 204n8), to provide some context that can help to better explain the conceptual pivot that I want to make away from only detailing and critiquing social reproduction and towards economic possibility and social change. Drawing from Gibson-Graham and Marcel Mauss, I then propose a theoretical framework that can help to illuminate non-capitalism and might point towards revolutionary transformation.

In the second section I discuss and compare two, very different political projects undertaken by green economy groups in Massachusetts:

\footnotetext{
${ }^{2}$ See Shear 2010 for my own optimistic performance of possibility in the green economy.

${ }^{3}$ These quotes - from a workforce development organization director, a community organizer working with youth collectives, an organizer for an environmental non-profit, and an activist with a former career in local government-are meant to signify the widespread, ubiquitous sense of possibility around the emerging green economy in 2008 and 2009.

${ }^{4}$ Greenwork has formed into a non-profit entity whose board is comprised of representatives from other community organizations, non-profits, and organized labor. Greenwork aspires to help support the creation of a "high road" green economy that is founded on principles of social justice, the right to organize, and community and worker-ownership. The group's primary activity since it's inception has been to convene regular "roundtable" discussions in which diverse actors are brought together to discuss, debate, and network around green economy initiatives.

${ }^{5}$ Of course not all non-capitalist practices are necessarily desirable, nor do they all encourage ethical values and practices (for example slavery or feudalism). Non-capitalism here is a sort of shorthand for social relations that can move us past the economic horizon provided by capitalist relations and values.
} 
1) A social justice campaign around energy efficiency work; and

2) a project to imagine and create a solidarity economy.

I explore how different desires for and disposition towards the economy animate and circulate through these projects. Finally, I take measure of how green economy coalitions are re-orienting to a changing political terrain, and I look for spaces and opportunities for political alliances around economic possibility.

\section{Green governmentality?}

On a global scale, and from the perspective of international policy-makers, the mainstream green economy project attributes economic and ecological crises to a "misallocation of capital", a mistake that can be rectified through the proper market incentives and the right policy prescriptions (UNEP 2011). These ideas are not altogether new; the green economy as a named, political project can be understood as both incorporating and extending other, interrelated global-environmental initiatives and discourses that have intended to capitalize and commodify nature including sustainable development, biodiversity conservation, and ecological modernization (Brockington and Duffy 2010; Escobar 1996; Escobar 1997; Igoe et al. 2010; MacDonald 2010; West and Brockington 2006).

Brockington and Duffy explain that while conservation and capitalism have always had a "close relationship", in recent decades "capitalist conservation" and its "aggressive faith in market solutions to environmental problems" (p.470) have become increasingly commonsensical; "the idea that capitalism can and should help conservation save the world now occupies the mainstream of the conservation movement" (470). In a similar vein, Escobar explains that the discourse of sustainable development proposes to commodify nature in order to facilitate conservation efforts and manage the ecologically destructive externalities of capitalist production and exchange (Escobar 1996). In contrast, Macdonald (2010) identifies ecological modernization as posing a "challenge" to sustainable development, pushing it past its ostensible imperative of limiting growth through the market and towards a vision that weds ecological responsibility with technological fixes and "new strategies of accumulation" (p.519). Ecological modernization "refuses to see the supposed trade-off between environmental concerns and growth" and instead tends to looks for "winwin" situations (Harvey 1996: 378). A similar marriage of economic growth and ecological health is at the heart of the green economy project. While the green economy includes ideas of conservation and sustainability, it is promised as a remedy to ecological crises while at the same time is "pro-growth, pro-jobs, and pro-poverty-reduction" (UNEP 2010: 6-7). In addition to regulating markets, the green economy finds solutions to social and environmental problems through the expansion and creation of new markets for capital investment, technological innovation, and job creation (ETC Group 2011; Pollin et. al. 2008; UNEP 2011).

In the U.S, green economy policy makers have focused on economic growth and job creation in the renewable energy sector, energy efficiency, and green building construction as part of a "clean energy economy". Massachusetts has positioned itself at the forefront of these happenings. In 2008 Massachusetts passed the Global Warming Solutions Act which mandates an $80 \%$ decrease in greenhouse gas emissions by 2050 (below 1990 levels), passed the Green Jobs Act which encourages and supports clean energy work, and created the Massachusetts Clean Energy Center-"the first state agency in the nation dedicated solely to facilitating the development of the clean energy industry" (https://www.facebook.com/MassCEC/info). "In addition, Massachusetts based companies and research institutions have received 17\%- or \$62.8million- of the federal dollars awarded through the first year of the US Department of Energy's Advanced Research Projects Agency-Energy (ARPA-E) program." (BW Research Partnership 2011: 2). Employment in the industry in Massachusetts grew by 6.7\% from 2010 to 2011 compared to a 1\% overall growth rate (BW Research Partnership 2011: 4). And in 2011 Massachusetts jumped ahead of California as the country's most energy-efficient state (ACEEE 2011).

It's interesting to note the different economic philosophies that surface and intermingle, even in this limited recounting of the mainstream green economy project. On the one hand, we can see a concerted shift 
away from some of the ideology and dogma associated with neoliberal capitalism. The very premise of the green economy concedes that "business as usual" resulted in economic and ecological crises, and thus we now need something different. Indeed, as a recent UN report on the Green Economy states, "unfettered markets are not meant to solve social problems" (UNEP 2011: 01 citing Yunus and Weber 2007). Instead of leaving markets alone, the green economy would regulate and reallocate capital through government intervention. In addition, the green economy has often been put forward as a Green New Deal (Dipeso 2009; Pollin 2009; UNEP 2009), in which government intervention, spending, and policy changes would create new jobs and save the (capitalist) economy. This idea, which also suggests a class compromise in which social antagonisms are resolved through economic growth, job creation and a redistribution of resources, has been attractive to organized labor and progressives (Baugh 2009; Apollo Alliance 2008).

On the other hand, the green economy can appear as a neoliberal project, proposing that it is the role of government to create new markets for capital investment and to use markets to manage nature and climate change. Despite its association with laissez-faire economics, neoliberalism involves the active creation of the conditions that will support new markets including the production of particular types of people, "...subjects whose moral quality is based on the fact that they rationally assess the costs and benefits of a certain act as opposed to other alternative acts" (Lemke 2001: 201). At a November 2011 state legislative hearing dealing with the growth in the energy efficiency industry in Massachusetts, a state official suggested that the green economy would be built through individual, self-interested decision making, "...as people learn they can save money [by doing energy efficiency measures] people are doing it because it makes sense."

In sum, we can see that the green economy—in its state-projected construction—can accommodate elements of both Keynesian regulation and neoliberal development discourse. And it should be no surprise then that both poles of the mainstream economic spectrum can support the creation of the green economy (for example, compare Friedman 2008 and Krugman 2010). Though not a cohesive project, the coordinates in this frame are precisely creating and incentivizing capitalist markets for investment and the creation of wage labor jobs.

It can be useful to understand this state-sponsored green economy project-which envisions a marketeconomy animated by homo-economicus - as a form of governmentality that seeks to discipline and produce people that will then reproduce capitalism. Though not completely cohesive or singular, the mainstream green economy project can aptly be characterized in terms of neoliberal environmentality (Fletcher 2010) ${ }^{6}$, a form of governmentality that mobilizes and incentivizes people to address "environmental problems... as issues that require cost benefit analysis" (p.176) and in which "economic growth is the chief mechanism through which the aims of bio-power are pursued" (p.175). The mainstream green economy project, in other words, works as a discursive apparatus that encourages people to imagine themselves and behave as selfinterested, resource maximizing, rational actors: homo-economicus, the subject of economy that capitalism requires.

While cognizant of how the green economy discourse might reproduce capitalist relations, I want to be careful in the way that I approach this problem; I am not interested here in simply looking for capitalist expansion and reproduction, or even resistance to it. Following Gibson-Graham, I am interested in locating and theorizing possibilities for non-capitalism, both at the level of the subject, and in terms of empirical, objective conditions. So, while acknowledging a discursive apparatus linked to capitalist reproduction that might be described in terms of a "neoliberal environmentality", I want to complicate this formulation in two ways in order extend the political terrain beyond a capitalist horizon.

\section{Non-capitalist practice and desire}

First, using Gibson-Graham's language of diverse economies, I choose to theorize the economy not as a homogenous, cohesive system that is capitalist in nature, but as different arrangements of surplus appropriation and distribution, and different forms of exchange, "scattered over a landscape" (Gibson-

\footnotetext{
${ }^{6}$ As Fletcher notes, there are certainly other discourses and forms of "environmentality" that overlap and intermingle with the neoliberal variety.
} 
Graham 1996: xxiv) and overdetermined ${ }^{7}$ in place (Gibson-Graham 1996; 2006). In this view of economy, we can treat capitalism as a capitalist firm producing or exchanging for a capitalist market; it's just one relatively modest portion of overall economic activity and relations that includes alternative markets like fair trade, farmers markets, and localism; non-capitalist relations of production like worker-ownership and community owned enterprises; CSA's and consumer cooperatives; household production, volunteerism, mutual aide, and other types of so-called informal economic activity; and so on. A language of diverse economies, for Gibson-Graham, is part of a politics that emboldens us to make ethical choices around our political-economic activity (Burke and Shear 2014). Economic identities, practices and relations become sites of possibilities for non-capitalism and the normal workings of capitalism are open for transformation. For example, by understanding class as a process that is created through different arrangements of production, appropriation and distribution of surplus, rather than a static social category that is prearranged in a hierarchy (Gibson-Graham, Resnick, and Wolff 2000), exploitation-the appropriation of surplus from producers by non-producers-becomes just one possibility for class relations among many. We can more readily see existing practices and possibilities for new social arrangements in relationship to surplus that are nonexploitative (for example, the collective appropriation and distribution of surplus that we find in worker collectives).

Second, I want to attend to Mauss's important insights around economic subjectivity (1990). Mauss sets out to prove that people can hold multiple economic motivations, and act on them, all at once. On top of this Mauss suggests - in a somewhat inchoate way, but the insight is powerful — that even in a world that is understood as dominantly capitalist, people want to and can make efforts to go beyond individualism and self-interest, efforts to be in common with each other (see Graeber 2001: 161-162). This is an important addendum to Polanyi's denaturalization of market economies and homo-economicus (Polanyi 1977; Polanyi 2001); though market economies depend on a philosophy that constructs individuals as self-interested, rational actors, Mauss tells us that those individuals aren't fully colonized by a "marketing mind" (Polanyi 1977). Indeed, following Mauss, Graeber suggests that we all might already be latent communists, waiting for an opportunity to express that part of ourselves (Graeber 2010a; 2010b).

With an imaginary of economic possibility in place, even in relation to a discursive regime like neoliberal environmentality, the nature of the economy itself becomes a political question. The political field is no longer circumscribed by capitalism, but is saturated by non-capitalist dispositions and desires (in addition to capitalist) and is populated by a full range of non-capitalist practices, enterprises, and relations. We might even be able to begin to understand ourselves — as researchers and as activists-as participating in an alter-hegemonic war of position, a cultural struggle in which we can build, amplify, organize around, and link up non-exploitative forms of non-capitalism, thus sucking capitalism of its material and discursive hold.

I now turn to an investigation of the economic desires and beliefs of green economy social actors. What do they want to do to change the economy and their relationship to it? How do particular imaginings of the green economy, and the economy more broadly, foreclose economic desires or help particular desires to be realized? The first project is a campaign positioned as part of a broad effort to create a socially just green economy by growing new markets and helping to create good-paying, wage-labor jobs. At the same time, this project in part adopts an anti-capitalist stance that situates it in opposition to and resisting the impacts of an economy understood as capitalist, externally imposed, and unyielding. The second project that is attempting to build a green solidarity economy, turns away from capitalism and adopts a stance of economic possibility that points towards a non-capitalist horizon. By stance I mean an ideological-emotional orientation towards an issue that both reflects and influences our thinking and actions (and see Gibson-Graham 2006: 1-11). Following Lacanian theory, I treat these projects as reflecting and rendering fantasies (Stavrakakis 2007; Zizek 1997) that carry particular conceptions of the economy that invest us with particular desires while

\footnotetext{
${ }^{7}$ Wolff and Resnick's elaboration of Althusserian overdetermination tells us that there is no essential quality or enduring essence to any particular entity (Wolff and Resnick 2006, 2012, 2013; Burke and Shear 2014). Individuals, sites, and institutions are in a dynamic state, "pushed and pulled" in a multiplicity of constitutive directions (Wolff and Resnick 2013: 342). Thus, we can't always predict how any person, group, institution or business will behave, or how any set of relations will proceed; they are radically contingent and open to intervention. Apropos non-capitalist possibility, we might read this open, unpredictability of overdetermination onto, for example, the choice of a large, successful capitalist business to transition into a worker cooperative (Morgan 2013).
} 
policing against others. To be clear, fantasy does not imply that people are fooled, misguided or are unaware of the conditions that they are in, quite the opposite in fact. Fantasies construct reality. They provide us with narratives from which to understand our selves and engage with the world. However, these explanations are never able to provide us with a completely rational and coherent basis for our actions; thus our identities are never fully complete and coherent. What helps to bridge this gap, and keep us firmly invested in particular fantasy formations, is the enjoyment that we get from our desires, and frustration of our desires, that are structured through fantasy. At the same time, since identities are not coherent, people have the potential to be affected and transformed by different and competing ideologies and discourses, including different understandings of the economy.

\section{Fantasy and economic possibility}

\section{The green economy and social justice}

In the spring of 2011, I took part in an energy efficiency charette at a hotel conference center in Eastern Massachusetts. The meeting was hosted by one of the major private energy utilities in the state and attended by representatives from other major utility companies, service providers, policy makers, and about 10 representatives, including myself, from a group that I will refer to as the Statewide Green Economy Coalition (SGC). Over the course of two days, we broke out into working groups to discuss ideas about how to solve the problem of "hard to reach, hard to serve" communities that were being excluded from energy efficiency and weatherization (weather proofing) programs that the utility companies were mandated to implement. These programs were in line with the state's energy efficiency goals, and would presumably lower energy bills and make homes more comfortable to live in. But, as the coalition argued, a huge segment of the state's population — primarily low-income communities and communities of color — that were paying monthly mandatory charges into the program, was unable to access it because of financial, language and cultural barriers. We in the SGC argued that, in effect, the system was compelling the lowest income households in the program to subsidize everyone else. To solve this problem, we proposed more effective forms of outreach that could also create good, green jobs and we argued that a redistribution of money in the program was needed to help more people afford weatherization costs. This in turn would increase the demand for energy efficiency services and thus create more good green jobs.

This meeting was the result of ongoing, multifaceted campaign efforts of the statewide coalition. The coalition, made up largely of community organizing groups, organized labor, and environmental groups formed in 2008 in order to intervene in the green economy to try and make sure it was socially and economically just. A campaign around energy efficiency work came together first because of the widely held belief by policy makers and progressive organizations that weatherization was the "low hanging fruit" for both job creation and carbon reduction; there was a great amount of resources and political attention directed towards energy efficiency. Over the two years leading up to the meeting, the coalition had engaged in a variety of tactics to move our issues forward including public demonstrations, public hearings, membership organizing, lobbying efforts, and pilot projects that were intended to model how energy efficiency work could create good jobs for organized labor, low-income communities, and communities of color; as well as ensure equitable access to the savings and comforts of weatherization. In short, it is a campaign for social and economic justice.

Indeed, the campaign engaged with the green economy as a way to counter the effects of and intervene against the broader economy. In contrast to the socially just, green economy the SGC was endeavoring to create, the nature of the broader economy was publicly described by the coalition, and was often discussed by members, as a force that creates social inequalities and structures individual and social suffering. For example, outreach materials included the description of economic and heath inequalities in Massachusetts and stated that "low-income communities and communities of color have been overburdened by our unsustainable economy".

To put this another way, for the SGC, the green economy was a vehicle for organizing around social, economic, and environmental justice principles that are in response to, and stand in opposition to, 'the economy.' Without opposition or intervention, the economy would continue to create inequalities and 
hardship. As the SGC warned in our outreach materials, growth in the green economy would not automatically benefit everyone. And green jobs would not automatically be good jobs - "without strong advocacy" green jobs could end up being low opportunity, low-paying, and unsafe. In other words, the SGC, and individual members of the coalition, positioned the economy as an inequality generator.

The SGC includes over a dozen organizations and hundreds of members, and people have different ideas and politics, as well as different conceptions and analyses of the economy. But for many of the primary organizers, the economy was synonymous with a conception of capitalism that is intrinsically exploitative and oppressive. As one organizer related to me on more than one occasion, "everyone I know is against capitalism, they just don't always call it that [publicly]", because of the possibility of being labeled a radical, being easily dismissed, or not be taken seriously. Though the SGC can be understood as having adopted a stance of opposition towards the capitalist economy in this campaign, the objectives of the campaign-to increase the amount of wage labor jobs and regulate capital-directly mapped onto the coordinates of the mainstream green economy project. In this campaign at least, the coalition supported and hoped to create the type of economy that the dominant green economy frame suggests, a growing and managed marketcapitalism populated by self-interested rational actors. From this frame, social justice concerns would seem to be resolved through maintaining and growing of the capitalist economy (and see Fletcher 2010: 176). Indeed, this strategy suggests that more equality requires the expansion of capitalism.

\section{Economic fantasy and anti-capitalism}

So what is going on here? Are green economy coalition members simply drawn up and produced through a neoliberal environnmentality, and turned into knowing or unknowing subjects? It's both difficult and problematic to try to explain the actions of the coalition, and subjectivities of coalition members, in terms of an interactive binary of structure and agency which forces people into categories of, on the one hand production by or compliance with structure and thus social reproduction; or on the other hand resistance or evasion of structure and thus social change. Among the coalition members that I struggled alongside, it just doesn't work like that. Coalition leaders and members are extremely savvy and sophisticated. The discursive structures of the state-sponsored green economy project are not unseen and the political constraints that ideology poses are examined and scrutinized. Many coalition members and leaders are long-term organizers, and are highly educated-both experientially in on-the-ground politics and in terms of formal education. In my interviews and conversations with SGC organizers, they are quick to acknowledge the "reformist" elements of the project and profess to desire a different form of economy, one in which capitalism isn't dominant or doesn't exist. In short, many coalition members are fully aware of the multiple contradictions related to capitalism that we are caught up in. People know that it is "the capitalist economy" that is creating inequality, exploitation and exclusion. ${ }^{8}$ And they would like something different. Yet, we were invested in a campaign that intends to reproduce capitalist relations, and the subject of homo-economicus that inhabits these relations, through the expansion of capitalist markets and commodity exchange.

Understandings the SGC's campaign as reflecting and rendering a social fantasy in relation to the economy (Byrne and Healy 2006; Healy 2010; Özselçuk and Madra 2005; Özselçuk and Madra 2010), might help to better explain these apparent contradictions that can keep people invested in capitalist reproduction even while opposing it. As Özselçuk and Madra explain, a "fantasy formation offers a narrative frame for the 'subject to experience itself as a desiring subject' in so far as it finds 'solutions' to the problems of the subject's desire by providing a rationale for dissatisfaction" (2010: 325 referencing McGowan 2007: 24). In other words, we create and participate in social life through narratives that make sense of our feelings of dissatisfaction or unease; they provide a basis for identity and social action. However, because we take pleasure in the entire fantasy, in both the idea and desire of achieving satisfaction as well as the frustration of reaching that goal, fantasies can have the perverse outcome of working to shore up the problem that we seek to confront.

\footnotetext{
${ }^{8}$ This is not to suggest that other relations of oppression are not relevant to or discussed by coalition members, but the campaign itself focuses on the economy — an economy that is understood as rife with different forms of oppression-as the system to oppose and improve.
} 
In the SGC campaign, one ultimate goal that animated activists and gave meaning to our work was social equality. Social justice work was made necessary in part by an imagining of the economy as an unyielding system which is structuring inequality, creating poverty and so on. Thus the economy must be resisted and opposed. At the same time the realization of social equality was and is frustrated by the very same capitalist economy which has the first and last word. It is this fantasy formation from which SGC members, including myself, experienced themselves and were motivated through in relation to this campaign.

For example, in explaining why good green jobs haven't been created at the rate that was initially hoped for, some coalition members expressed a grim resignation- as do green jobs supporters more generallyto the fact that this situation is simply the result of an unassailable economic system. As one coalition member explained, "on the national level, we are all [green jobs organizers and advocates] bummed that we didn't create as many jobs as we wanted, and we are just going to keep slogging away until the economy picks up." In other words, though our campaign objective is to create more equality through efforts in the green economy in order to create a socially just economy, on some level we know that this is not really possible since it is at the mercy of the [capitalist] economy, which is ultimately in charge.

One community organizer asserted after a campaign meeting that capitalism was a central cause of those racialized inequalities and environmental injustice that the campaign was addressing. It was capitalism that the campaign was opposed to and hoping to change. A few minutes later I asked her if she thought that the campaign was going to be able to transform the capitalist economy that was creating these problems; she responded vehemently; "...of course the campaign isn't trying to change capitalism! We are trying to create good jobs." Capitalism here can be both the cause of social inequality while at the same time also looked to as the solution to inequality.

Another coalition member explained her investment in the coalition as an opportunity to help ensure a "...sustainable economy, something that we can see continuing into the future....an economy that raises the standards of living for all people and makes good use of our resources". When asked what it would take to create this fair and just economy she leaned in conspiratorially and said; "I actually think we need to break the economy!" Then more resigned; "It's going to take maybe the market just imploding altogether. I don't know (laughter)." Here, the desires for another economy, even though they are present, remain outside of the imaginary, outside of what is actually possible, unless "the market just implod[es] altogether."

In the above examples, we can see capitalism enter as the Lacanian 'Big Other', the believed in symbolic order that 'tells' the subject how and what to desire (Salecl 2011: 58-60). The desires for another economy besides capitalism that many members hold and sometimes express can be made to seem laughable and unimaginable by capitalism's symbolic authority. Though capitalism might be impossible to transform, we can at least busy ourselves and take pleasure in what the Big Other permits. For example, we can take pleasure in doing the work of "slogging away" against capitalism and towards social justice, as well as take some 'pleasure' in "the capitalist economy" which frustrates and makes possible our desire to oppose it, or we can even desire capitalism as a solution to itself, even when we know on some level that it is really no solution at all. Of course, slogging away against capitalism is certainly commendable, important work, which can result in very tangible and substantial reforms and benefits. My interest here, however, is in how "enjoyment" in taking action to achieve our desire, and the frustration of our desire-our enjoyment in opposing capitalism—-might also have the perverse effect of investing us in a project to reproduce it.

\section{Green solidarity economies}

In the spring of 2011, I joined the planning committee of a very different project and intervention in the green economy, a planning committee for a conference to discuss and help to build a green solidarity economy in Central Massachusetts. Over the next few months, at weekly meetings, held at local coffee shops, cooperative houses, and community organization offices, I participated in debates and discussions about how to best educate about, represent, and build relationships around green solidarity economy activity which the committee ultimately defined publicly as: 
...commercial and non-commercial activity oriented to meet individual and collective social needs over profit maximization. It is organized through various kinds of voluntary or cooperative associations within communities. The definition (re)centers the principles of solidarity, sustainability, equity, participatory democracy, and pluralism as the core values of interpersonal relationships and exchange.

The summer conference was held at a local youth center and featured over 20 sessions including workshops on cooperative culture, financing cooperatives, solar barn-raisings, alternative currencies, food justice, and building an alternative economy. Close to two hundred people participated in these sessions, chatted in the hallways, ate lunch together, created new friendships, and learned about each other's projects. In a grassy area outside that ran the length of the building, people traded clothes, housewares and other stuff at a barter market, took home clothes and books from a "really, really free market", traded expertise in a skill exchange, or just sat around and talked and soaked in the warm, summer sun.

The conference developed out of a group that I will refer to as the Central Massachusetts Green Jobs Coalition (CJC) that emerged in 2009. The coalition was spurred in part by a desire to amplify the activity that groups in the area were already doing, and link up to the growing movement. As one member said, "we felt like we were already doing green economy and green jobs work, we just didn't call it that." Indeed, the lead organization of the CJC is a grassroots collective that houses an environmental justice and youth cooperative, and a co-op development program. This organization itself is nested in an artist and activist collective that included a number of alternative economic and non-capitalist programs and organizing groups like a Food Not Bombs chapter, a cooperative bicycle program, and independent media.

Like the SGC campaign, the CJC held a vision of social justice, but one that was inflected with an additional and different set of economic desires. One of the main organizers and leaders of the CJC stated their view of a green economy: "it's about local autonomy" and "we want to own our own jobs." And in describing how we can live in solidarity and sustainably in relation to the green economy, he said "people need to commit to each other. I'll be there for you; you'll be there for me. That's the idea of solidarity for me." For the CJC, the green economy was not primarily a strategy to oppose the existing economy, or solely an effort to try and make the capitalist economy more equitable. It was a frame from which to make a new economy, one that largely dis-identifies with capitalism. In other words, the economic desires put forward here were for something in addition to or other than the values of individualism, competition, and economic rationality, something other than those ascribed to homo-economicus; they are about control of economic activity, ethical decision making, and being in common with one another in and through our economic practices. Prior to the conference, the coalition and its members had worked hard to put those values into practice through the energy and ideas around a green economy. For example, different organizational members developed two community gardens. And, a bio-diesel cooperative and a volunteer weatherization barn-raising organization also emerged in relation to green economy discussions and efforts.

Whereas the SGC campaign rendered a fantasy that administered desires for capitalism, possibilities and desires for non-capitalist values and practices circulated freely at the solidarity economy conference, and within the CJC in general. Indeed, after the conference, the CJC more formally adopted solidarity economy principles and embarked on a re-visioning process that resulted in removing the words "green jobs" from its title. A community organizer who first proposed this change explains, "green jobs doesn't really fit with what we want to do. We don't want to just create capitalist jobs within capitalism." And "it [the term 'job'] signals that someone else needs to provide employment for us."

\section{Race, class, and economic desire}

At the conference, the dominant narrative that was put forward allowing us to experience the economy as desiring subjects was one of economic possibility. Rather than a capitalist economy that was externally imposed, the economy was something to be defined, something in the making. Could we not, in fact, if we chose to do so, create the types of economic relationships that would allow us to be in common with each other rather than compete against each other, to make ethical decisions through our formal economic practices, and to value people and the environment over profit? This narrative flowed naturally from 
organizations and individuals that got involved from the CJC, who were already creating and participating in non-capitalist and alternative economic endeavors. Moreover, a number of the more consistent members of the planning committee were familiar with the ideas of, or had even studied under J.K. Gibson-Graham. ${ }^{9}$ I joined the planning committee of the conference more than mid-way through the planning process and also contributed to the discussions, planning, and promotional text. As the conference began to take shape, it become apparent that the vision for a solidarity economy that would be performed included a full range of non-capitalist possibilities and in many ways paralleled the diverse economies imaginary of Gibson-Graham. Like most involved, I was generally quite excited.

At the same time, there was some shared concern leading up to the conference about what might be missing or excluded. A few of us noted that, though our promotional literature framed the conference as an attempt to locate solutions to the problems created by "corporate capitalism", there didn't appear to be many sessions or planned events focused on organizing for change, or confronting "power". We wondered if this might create an apolitical frame that elided or deprioritized racialized economic inequalities and social oppression. Others in the group suggested that the language we were using to promote the conference and talk about politics had an academic tone to it that indexed a middle class, college-educated audience. Even more apparent, and much discussed both prior to and after the conference itself, was the lack of racial diversity in the composition of the planning committee and among session facilitators and presenters. We worried and anticipated, correctly, that most people attending the conference would be white and/or would be of a particular social class: "middle class", "college educated", "academics", "progressives".

A few organizers and leaders from base-building community groups comprised of poor people of color, and a few community-labor organizers from outside the CJC participated in the conference, including some from the SGC. Those that I spoke with and interviewed reported similar reactions; though appreciative of the invitation and the opportunity to participate, they were at the same time generally turned off. The high percentage of white faces was unanimously remarked upon. But described as even more problematic was the feeling that there was little recognition, let alone discussion, of the ways in which social and economic processes were structuring inequalities and oppression.

Brian, a staff member of an organizing group led by low-income people of color described the conference this way.

It was okay. It's great that people can have the time to 'imagine another world' [making finger quotations] but that's just not the reality [for people in his community organization]. I think that what they [most of the people at the conference] don't realize is that it's really, really hard for poor people and people of color to do what they are proposing.

This claim deserves further thought, both in terms of its subjective meaning and its empirical validity. In describing the origins of the solidarity economy in Latin America, Miller (2006) identifies two distinct social groups who were its primary progenitors: the very poor who had been systematically excluded from the capitalist economy and were "forced to develop" non-capitalist institutions and relations, and relatively privileged people who were dissatisfied with the "culture of the dominant market economy" and sought "new ways of generating livelihoods and providing services." For the very poor, non-capitalist practices were a necessity; for the privileged, non-capitalism was a choice, a luxury of privilege. However, neither of these categories seem to adequately capture the situation of many people in low income communities in Massachusetts who are intensively exploited and oppressed but not yet completely abandoned by the state.

Brian went on to argue that people who are working two part time jobs and are scrambling each month to pay bills and hold their families together don't have the luxury of getting involved in alternative economic projects, or have the same type of invested interest in doing so; "it's not simply 'a choice', he said. "[at the conference] there was no discussion of racism or class even...no discussion of racial or economic disparities...it was like a solidarity economy was all about individual choice, like a buffet of options that you

\footnotetext{
${ }^{9}$ Julie Graham taught geography at the University of Massachusetts Amherst from 1984 until her death in 2010. She and Katherine Gibson, University of Western Sydney, Australia used the blended pen-name J.K. Gibson-Graham.
} 
could choose from, 'here's a worker co-op, here's a time bank, everyone can just choose!"' Brian made this final, sardonic point with the knowing cynicism of a person sharing in the daily struggles of low-income communities and low-income communities of color who are particularly oppressed and whose choices are particularly constrained.

Brian's statements suggest multiple material and affective constraints on non-capitalist politics. First, he is indicating that the degree and intensity of exploitation and social oppression imposed on low-income people and people of color is much more likely to be greater than, for example, middle-class, college educated white people. Indeed, the lives and bodies of low income people and people of color are often under more direct social and economic constraints, are under more state regulation and surveillance, are targeted for more violence, and experience more stress and illness via social hierarchies than the general population (Davis 2006; Nguyen and Peschard 2003; Velez 2013). It would be a mistake, however, to assume that these conditions necessarily diminish the possibility for non-capitalist practices and visions. Indeed, oppressed communities and individuals in the United States "have a long and rich history of participation in unpaid activism and volunteerism" (Hyatt 2011: 116), have created resilient economies through reciprocal ties, mutual aide, and gift exchange (Stack 1974), and have created cooperative and alternative economic structures as development strategies and as part of socially transformative movements (Nembhard 2006; Shipp 1996; The Black Panther 1967). Nevertheless, facing and experiencing structural violence complicates and constrains daily life, nevermind efforts towards the creation of new economic ideas and projects.

But the concerns that Brian and others expressed are not simply about presumed structural differences between differently positioned socio-economic groups. What is also at issue here are the ways in which particular social fantasies attract or repel individuals and groups through their libidinal investments. Without a more concerted discussion of how the solidarity economy can be organized to oppose impacts of capitalist exploitation, racism and other forms of oppression, the conference produced a fantasy frame in which people were implored to take pleasure in simply choosing to engage in alternative economic activity and cooperative relationships; not doing so would prevent a coherent, cooperative economy from emerging. This fantasy formation can invest some people with desires to participate in alternative economic initiatives, but also can have the effect of eliding desires for anti-capitalist, social justice work, and undermine efforts at alliance building. A community organizer in the CJC who has been involved a wide array of resistance efforts as well as cooperative development gave shape to this concern when we discussed the criticisms of the conference. "I see it quite a bit...[people involved with] cooperative and sustainability, they don't show up for events and campaigns" that are more about social and economic justice. He went on to explain that he thought that the interest for some people involved with alternative economics is just about themselves individually participating in a co-op. From this perspective, 'solidarity economy' work is imagined as the domain of the relatively privileged who aren't as intensively subjected to daily policing, precarity, and surveillance, and who are relatively free to enjoy engaging in self-indulgent economic experiments. ${ }^{10}$

\section{Conclusion: a politics of economic possibility}

For conceptual clarity, up to this point I have treated the two projects as fairly separate and discreet entities, in order to mark and explore how different desires circulate in and around particular conceptions of the economy, and animate subjects in different ways. In the CJC, desires for non-capitalism freely come to the fore, sometimes occluding interests and desires for oppositional politics and social justice concerns. In the statewide campaign, an anti-capitalist stance in relation to social justice can lead to an investment in and attachment to capitalism.

These narrative formulations, these economic fantasies, are powerful. They can work to fix identities and create desires for particular types of social action and disperse others, thereby creating divisions and disarticulations that can constrain political movements and limit economic and political possibility. Thankfully, real life is messy. Individual organizers and members encounter and embrace a variety of competing stances, positions and desires that are activated as identities are challenged and shift in relation to

\footnotetext{
${ }^{10}$ A favorite easy target are time-banks which some of my organizer friends dismiss as "a game" for progressive white people who want to "trade reiki for ballroom dancing lessons."
} 
different and changing social discourses, contexts and encounters. The social fantasies emergent in the projects are not always life consuming and are not the only ones that coalition members invest themselves in. For example, while discussing the green economy, social justice project she was involved in, an SGC staff organizer reconciled her misgivings about the reformist elements of the project by distinguishing the professional and paid side of her political identity from her unpaid political self which was reserved for what she described as a more radical politics that included desires to create alternative economic structures.

Progressive politics in Massachusetts appears to be getting even messier, helped along considerably by the green economy. As promised, the green economy has brought together new progressive alliances and interests in new ways. As these alliances form, different people with different interests have conversations, learn from each other, build relationships and politicize each other new conversations about and initiatives for economic possibility emerge. Indeed, despite the campaign's investment in social and economic justice through market regulation, redistribution and capitalist reproduction, some discussions about community ownership and cooperatives have been with the SGC since its inception. Initially, there was even an effort among some organizations in the coalition to create an energy cooperative, which was ultimately unsuccessful. But the seeds from this failed effort, as well as ongoing conversations from different coalition members with growing involvements in alternative economics are transforming the political (and economic) terrain. More recently, a campaign has developed around recycling involving a few organizational members of the original coalition of the SGC, the goals of which involve the creation of worker cooperatives. And, conversations about alternative economics, cooperatives and solidarity economy are increasingly taking place both informally, and in formal discussion groups. According to one of the group's participants, these efforts are an outcome of the relationships built and ideas exchanged in the SGC and related networks.

For its part the CJC has redeveloped its political platform in direct relation to internal and external critique of the 2011 conference. After numerous conversations and reflection in meeting after meeting, as well as with allies who were critical of the conference, the CJC decided that in order to be transformative, in order to be able to actually create the economy that we wanted, a solidarity economy must explicitly include more than a vision and desires for non-capitalism. Reflecting this re-theorization, the 2012 conference was based on the development of a tripartite model that includes:

1. Alternative economics-initiatives, enterprises, trade and finance that privilege community and ecological well being over individual gain (e.g. worker cooperatives, community ownership, fair trade, time-banking, credit unions, community land trusts and commons management, and so on).

2. Resistance and reform- working against environmental degradation, social inequality, and poverty by improving policies around existing system (e.g. living wage ordinances, union contracts, immigration reform, energy policy, progressive taxation, environmental regulation, social welfare programs, and so on).

3. Social inclusion- efforts to end racism, sexism and other forms of oppression and exclusion (affirmative action and hiring policies, popular education and workshops, and so on).

With this new model, the CJC is attempting to create a narrative frame which can encompass multiple economic stances and desires and from which we can build the relationships that can bridge and merge noncapitalist and anti-capitalist politics ${ }^{11}$. After the 2012 Conference, the CJC began an initiative to map-out the solidarity economy in Worcester and through this mapping exercise, and engaged in relationship building and organizing in order to continue to broaden the frame and expand the CJC.

Gibson-Graham suggest that the subject of anti-capitalism, immersed in capitalocentrism, needs to be overcome. To move away from the economic fantasies that position a systemic capitalism as the dominant symbolic order - the Lacanian Big Other that defines the parameters of our actions - they propose a language of diverse economies in order to cultivate new economic subjects and desires. This is a powerful intervention,

\footnotetext{
${ }^{11}$ It should be noted that an embracing of and emphasis on social justice and efforts towards social inclusion is not uncommon to other solidarity economy groups in theory (Kawano 2013) and in practice. Indeed, the CJC model was inspired by conversations with a practitioner of Brazil's solidarity economy.
} 
and one that is particularly suited for a certain type of Marxist that is unable to imagine actually existing revolutionary politics. From my perspective, this means the development and proliferation of the type of post-capitalist politics that Gibson-Graham propose, in which communities can collectively make ethical economic choices depends on making visible, supporting, and organizing around non-capitalist enterprises and practices (Gibson-Graham, Cameron, and Healy 2013). What's interesting, however, is that efforts and desires to create non-capitalist relations don't always correspond to a post-capitalist, or even non-capitalist political imaginary. For example, Terry, an SGC community-labor organizer describes cooperatives as "having an important place in the movement" and as constituting good, secure jobs. "I have really come around to your [mine and others who are proponents of alternative economics] way of thinking about worker cooperatives", Terry said. "It's because of conversations that I have had with people like you, Linda, and Carl...[now] I see co-ops as helping to build power in places where unions don't exist", and "it's another way to grow the movement". This was a significant change for Terry who just over a year earlier had laughed off the possibility of worker cooperatives as a socially transformative strategy. "Oh yeah, co-ops are so revolutionary!" he would say sarcastically, when I would suggest that co-ops and other diverse economy relations and practices could be a way to move beyond reform. What's significant here is that, though Terry's new interest in co-ops can be attributed in part to conversations that he has had with people who understood cooperative development as creating a new economy, his own economic identity is still securely fastened in opposition to capitalism. Indeed, Terry positions co-ops here as part of an anti-capitalist politics that can help build "the movement" and/or provide good jobs for people that need them.

This exercise can even be taken a step further to consider the ways in which non-capitalist enterprises and practices can be understood and desired within a frame of capitalist development. For example, the Evergreen Cooperatives network in Cleveland has begun to create worker-owned cooperatives whose employee-owners come from low-income communities and communities of color in which the businesses are located. It is particularly interesting is that the primary actors behind the network's development include some of the local political establishment. Planning and resources for the businesses was largely marshaled through the efforts of philanthropic foundations, and the enterprises are intended to be supported through the purchasing power of local "anchor institutions" (hospital, university and so-on) who agree to buy co-op products and services.

A similar initiative to develop green worker-owned enterprises is now underway in Springfield, Massachusetts. One of the project founders, a local community organizer, has been integrally involved in all of the planning meetings and conversations involved with the different establishment players involved in the project, including developers and potential anchor institutions. In considering the motivations of the more establishment individuals and organizations involved in the project, he said that it was apparent that there was more going on than only market logic and economic self-interest; they also cared about the well-being of the community and the people that lived there, "their reasons [for being involved] are pretty complex, more complicated than you would think." And if we choose to be more cynical, this project can also be positioned as neatly fitting into a vision of capitalist values and development. Indeed, the idea of creating businesses that people own and operate themselves is supported by capitalist values of entrepreneurship, individual responsibility, and hard work. And, during a public announcement of the project, Springfield's Mayor explained that this initiative answered the demand for the city's economic growth and "jobs, jobs, jobs".

Despite the predominant discourses associated with the mainstream green economy project, the green economy is a contingent, undetermined, economic space full of circulating desires, ideologies and fantasies, and a full range of capitalist and non-capitalist relationships and practices. Like the economy writ-large, it's in the process of being made, its shape and contours are contingent and open to transformation. Following Gibson-Graham, a primary task for activist scholars, and political actors more generally should be to punch a hole in the discursive dominance of capitalism which helps to confine the field of possibility to opposition and resistance to capitalism, and ultimately its reproduction. Activists and scholars are interested in creating a world in which economic relationships and practices encourage and enable us to act ethically and be in common with each other-instead of forcing us to exploit each other and adhere to market logics. As attempts are made to open up economic possibilities and desires through discursive intervention, it's important to attend to the ways in which anti-capitalist, and even capitalist, fantasies and desires might 
articulate with a project to create objectively existing non-capitalism. In the case of the latter, we might quietly help to build the economic enterprises and relations that enable people to operationalize their latent non-capitalist values and dispositions. In the former case, we can help strengthen alliances for both anticapitalist and non-capitalist political struggle.

\section{References}

ACEEE, American Council for an Energy-Efficient Economy. 2011. Massachusetts overtakes California as \#1 energy efficient state, Michigan and Illinois among the most improved. Press release. Oct. 20.

Apollo Alliance. 2008. The new Apollo program, clean energy, good jobs: an economic strategy for American prosperity.

Baugh, B. 2009. Standing at the crossroads: green jobs for a blue economy. In F. Scott (ed.) Working on change: the trade union movement and climate change. London: Green Alliance.

Brockington, D. and R. Duffy. 2010. Capitalism and conservation: the production and reproduction of biodiversity conservation. Antipode. 42 (3): 469-484.

Burke B.J. and B.W. Shear. 2014. Introduction: engaged scholarship for non-capitalist political ecologies. Journal of Political Ecology 21: 127-144.

BW Research Partnership and the New England Clean Energy Council. 2011. Massachusetts clean energy industry report. Massachusetts Clean Energy Center. http://www.greenneedham.org/blog/wpcontent/uploads/2011/10/MassCEC-Industry-Report-2011.pdf

Byrne, K. and S. Healy. 2006. Cooperative subjects: toward a post-fantasmatic enjoyment of the economy. Rethinking Marxism 18(2): 241-258.

Davis, D. 2006. Battered black women and welfare reform: between a rock and a hard place. State University of New York Press.

Dipeso, J. 2009. Energizing the economy: Obama's plan for green growth. Environmental Quality Management 18(3): 93-98.

Escobar, A. 1996. Construction nature: elements for a post-structuralist ecology. Futures 28(4): 325-343. . 1997. Cultural politics and biological diversity: state, capital, and social movements in the Pacific Coast of Colombia. In R.G. Fox and O. Starn (eds.) Between resistance and revolution: cultural politics and social protest. New Brunswick: Rutgers University Press. Pp. 40-64.

ETC Group. 2011. Who will control the green economy? Communique no. 107. ETC.

Fletcher, R. 2010. Neoliberal environmentality: towards a poststructuralist political ecology of the conservation debate. Conservation and Society 8(3): 171-181.

Friedman, T. L. 2008. Hot, flat, and crowded: why we need a green revolution and how it can renew America. New York: Farrar, Straus and Giroux.

Gibson-Graham, J.K. 1996 (2006). The end of capitalism (as we knew it): a feminist critique of political economy. Minneapolis: University of Minnesota Press. . 2006. A postcapitalist politics. University of Minnesota Press: Minneapolis.

Gibson-Graham, J. K., S. Resnick, and R. Wolff (eds.). 2000. Class and its others. Minneapolis: University of Minnesota Press.

Gibson-Graham, J.K., J. Cameron, and S. Healy. 2013. Take back the economy: an ethical guide for transforming our communities. Minneapolis: University of Minnesota Press.

Gill, S. 2008. Power and resistance in the new world order. Palgrave and MacMillan.

Graeber, D. 2010a. Communism. In K. Hart, J-L. Laville, and A.D. Cattani (eds.) The human economy. Malden, MA: Polity Press. Pp. 199-210.

. 2010b. On the moral grounds of economic relations: a Maussian approach. Working Papers Series \#6. Open Anthropology Cooperative Press.

2001. Toward an anthropological theory of value: the false coin of our own dreams. New York, NY: Palgrave.

Hall, S. 1987. Gramsci and us. Marxism Today June: 16-21.

Harvey, D. 1996. Justice, nature, and the geography of difference. London: Blackwell. 
Healy, S. 2010. Traversing fantasies, activating desires: economic geography, activist research, and psychoanalytic methodology. The Professional Geographer 62(4): 496-506.

Hyatt, S. B. 2011. What was neoliberalism and what comes next? The transformation of citizenship in the law-and-order-state. In C. Shore, S. Wright, and D. Pero (eds.) Policy worlds: anthropology and the analysis of contemporary power. New York: Berghahn Books. Pp. 105-123.

Kawano, E. 2013. Social solidarity economy: toward convergence across continental divides. UNRISD, United Nations Research Institute for Social Development. Feb. 26.

Krugman, P. 2010. Building a green economy. The New York Times Magazine. April 7.

Igoe, J., K. Neves and D. Brockington. 2010. A spectacular eco-tour around the historic bloc: theorizing the convergence of biodiversity conservation and capitalist expansion. Antipode 42(3): 486-512.

Jones, V. 2008. The green collar economy: how one solution can fix our two biggest problems. New York, NY: Harper Collins.

Lemke, T. 2001.'The birth of bio-politics': Michel Foucault's lecture at the college de France on neo-liberal governmentality. Economy and Society 30 (2): 190-207.

Macdonald, K. I. 2010. The devil is in the (bio) diversity: Private sector "engagement" and the restructuring of biodiversity conservation. Antipode. 42(3): 513-550.

Mauss, M. 1990(1924). The gift: the form of reason for exchange in archaic societies. New York: W.W. Norton.

McGowan, T. 2007. The real gaze: film theory after Lacan. Albany: SUNY Press.

Miller, E. 2006. Other economies are possible! Organizing toward an economy of cooperation and solidarity. Dollars and Sense.

Morgan, D. 2013. Making a new economy: getting cooperative. Truthout. Mar. 16

Nembhard, J.G. 2006. Principles and strategies for reconstruction: models of African American communitybased cooperative economic development. Harvard Journal of African American Public Policy XII: 3955.

Nguyen, V-K. and K. Peschard. 2003. Anthropology, inequality, and disease. Annual Review of Anthropology 32(1): 447-474.

Özselçuk, C. and Y. M. Madra. 2005. Marxism and psychoanalysis: from capitalist-all to communist non-all. Psychoanalysis, Culture, and Society. 10(1): 79-97. . 2010. Enjoyment as an economic factor: reading Marx with Lacan. Subjectivity 3(3): 323-347.

Polanyi, K. 2001 (1944). The great transformation: the political and economic origins of our time. Boston, MA: Beacon Press.

1977. The economistic fallacy. Review. 1(1): 9-18.

Pollin, R. 2009. Building the green new deal in the United States. Harvard University Kennedy School.

Pollin, R. and H. Garrett-Peltier, J. Heintz, and H. Scharber. 2008. Green recovery: a program to create good jobs and start building a low-carbon economy. University of Massachusetts Amherst: Department of Economics and Political Economy Research Institute.

Salecl, R. 2011. The tyranny of choice. UK: Profile Books Ltd.

Shear, B.W. 2010. The green economy: grounds for a new revolutionary imaginary? Rethinking Marxism 22(2): 203-210.

Shipp, S.C. 1996. The road not taken: alternative strategies for black economic development in the United States. Journal of Economic Issues. 30 (1): 79-95.

Stack, C. 1975. All our kin: strategies for survival in a black community. New York: Harper \& Row.

Stavrakakis, Y. 2007. The Lacanian left: psychoanalysis, theory, and politics. Albany, NY: State University of New York Press.

The Black Panther. 1967. Nov. 23. 3. http://www.stanford.edu/group/blackpanthers/history.shtml

UNEP. 2009. Global green new deal: policy brief.

UNEP. 2010. Green economy: developing countries success stories.

UNEP. 2011. Towards a green economy: pathways to sustainable development and poverty eradication. A synthesis for policy makers.

Velez, D.O. 2013. Stop-and-frisk on trial. Daily Kos. Mar. 24. 
West, P. and D. Brockington. 2006. Some unexpected consequences of protected areas: an anthropological perspective. Conservation Biology 20 (3): 609-616.

Wolff, R.D. and S.A. Resnick. 2006. New departures in Marxian theory. New York, NY: Routledge. . 2012. Contending economic theories: neoclassical, Keynesian, and Marxian. Cambridge, MA: MIT Press.

.2013. On overdetermination and Althusser: our response to Silverman and Park. Rethinking Marxism. 25 (3): 341-349.

Yunus, M. and K. Weber. 2007. Creating a world without poverty: social business and the future of capitalism. Philadelphia, PA: Public Affairs and Perseus Books.

Zizek, S.1997. The plague of fantasies. London: Verso. 